\title{
Leptin ameliorates testicular injury by altering expression of nitric oxide synthases in diabetic rats
}

\author{
Kapucu A, Akgun-Dar K \\ Department of Biology, Faculty of Science, Istanbul University, Istanbul, Turkey. akapucu@istanbul.edu.tr
}

\begin{abstract}
OBJECTIVES: We aimed to evaluate the effects of leptin and nitro-L-arginine methyl ester hydrochloride (L-NAME) on testicular damage and expression of nitric oxide synthase (NOS) types (neuronal, endothelial and inducible NOS) in streptozotocin (STZ) -induced diabetic and non-diabetic rats.

METHODS: Testicular damage was evaluated histologically and expression of NOSs was evaluated immunohistochemically in testis. Plasma leptin level and blood glucose level were assessed.

RESULTS: Blood glucose levels increased in all diabetic groups. L-NAME reduced it, but leptin had no effect. Three types NOS expression were shown in germ cells immunohistochemically. Increased eNOS and iNOS expression and decreased nNOS expression was detected in diabetic group. Testicular damage was observed in diabetic groups. Leptin ameliorated the damage by reducing iNOS expression and L-NAME partially prevented injury by supressing excessive NO production in diabetic rats.

CONCLUSIONS: It can be suggested that leptin and L-NAME partially prevents testicular damage by ameliorating histopathological changes by stimulating and /or supressing three types of NOS expression in diabetic rats. Leptin exhibited its effects by reducing iNOS expression in diabetic rats. This is the first report demonstrating the relationship between leptin and nitric oxide in testicular tissue in STZ-induced diabetic rats (Fig. 3, Ref. 33). Text in PDF www.elis.sk KEY WORDS: diabetes mellitus, testis, leptin, nitric oxide synthase, L-NAME.
\end{abstract}

\section{Introduction}

Diabetes mellitus (DM) is associated with an impairment in male reproductive system such as: testicular dysfunction, decreased fertility, impotency (1). Fertility, proliferation ability, testicular sperm count and mobility are significantly reduced in streptozocin (STZ)-induced diabetes model $(2,3)$.

Nitric oxide (NO) serves as a mediator in physiological functions by expressing three types of nitric oxide synthase (NOS) in the reproduction system (4). Endothelial-NOS (eNOS) expression has been detected in Leydig and Sertoli cells, and at all stages of spermatogenesis, in peritubular myoid cells, smooth muscle and endothelium of blood vessels, inducible-NOS (iNOS) expression has been shown in Leydig cell and neuronal-NOS (nNOS) expression was detected in Leydig cells and tunica adventitia of vessels in testis (5). Also, in-vitro studies reported that NO increased the ability of motility and acrosomal reaction in spermatazoa (6).

Department of Biology, Faculty of Science, Istanbul University, Istanbul, Turkey

Address for correspondence: A. Kapucu, Department of Biology, Faculty of Science, Istanbul University, Fatih-Istanbul, Turkey.

Fax: +90 2125190834

Acknowledgement: Our work was supported by Scientific Research Project Coordination Unit of Istanbul University, as project number T-713/30062005.mmm
Leptin plays a role in food intake, energy expenditure, continuation of reproductive function (7). Leptin mutants (ob/ob) mice are congenitally obese and infertile (8). In the patients with leptin gene mutation congenital obesity, insulin resistance and hypogonadotropic hypogonodism were observed (9). Low leptin levels are associated with disorders such as: hypertriglyceridemia and insulin resistance associated with diabetes. Leptin treatment reduces the risk of pathological conditions of diabetes. Therefore, leptin is thought to regulate overall body sensitivity to insulin and triglyceride levels (10).

We focused on the prevention of damage by diabetes and the relationship between the nitric oxide and leptin in testis. We aimed to determine the structural changes and distribution of nNOS, eNOS and iNOS in the testis of STZ- induced diabetic rats and to investigate the effects of single or combined treatment with leptin and nitro-L-arginine methyl ester hydrochloride (L-NAME), a general NOS inhibitor, on testis in type 1 diabetes animal model.

\section{Material and methods}

\section{Animals}

Healthy 3 month-old 250-320 g male Wistar albino rats used in accordance with the Animal Welfare Act and Guide for Istanbul University. The rats were maintained with a $12 \mathrm{~h}$ light: $12 \mathrm{~h}$ dark cycle at $23 \pm 2{ }^{\circ} \mathrm{C}$ and fed with standard pellet diet and tap water ad libitum. 
111-115

\section{Experimental protocol}

Animals were divided into two main groups as the control group, which received intraperitoneal (i.p.) injections of physiological saline and diabetes induced by single dose of $65 \mathrm{mg} / \mathrm{kg} / \mathrm{i} . \mathrm{p}$. STZ induced as in our previous study (11). Three weeks after the STZ injection, rats were divided into 7 groups $(n=6)$ treated daily for 1 week with the following protocol. Group I: The control group received a saline by i.p. injection. Group II: Diabetes group animals were given $0.5 \mathrm{ml}$ saline i.p. injection. Group III: animals were given leptin $(0.5 \mu \mathrm{g} / \mathrm{kg}$, i.p., Biomol Hamburg, Germany) in $0.5 \mathrm{ml}$ saline. Group IV: animals were given L-NAME $(30 \mathrm{mg} /$ $\mathrm{kg}$ /i.p., Sigma Aldrich, St. Louis, MO) in $0.5 \mathrm{ml}$ saline. Group V: STZ+Lept group animals received leptin $(0.5 \mu \mathrm{g} / \mathrm{kg}$, i.p. $)$ in 0.5 $\mathrm{ml}$ saline. Group VI: STZ+L-NAME animals received L-NAME (30 mg/kg i.p.). Group VII: STZ+L-NAME + Lept animals were given L-NAME $(30 \mathrm{mg} / \mathrm{kg})$ and leptin $(0.5 \mu \mathrm{g} / \mathrm{kg})$.

After the last treatment, the blood glucose levels were assessed and animals were anesthetized by intraperitoneal administration of $90 \mathrm{mg} / \mathrm{kg}$ sodium pentothal. The blood samples were drawn by the cardiac puncture and the testis were dissected and specimens were obtained and processed for histological examination under anaesthesia.

\section{Histological and immunohistochemical examination}

Testicular damage was detected by using haematoxylin and eosin staining and histopathological changes were estimated under a light microscope. Expression of eNOS, nNOS and iNOS in testis sections were detected by using avidin biotin complex (ABC) method as described in our study (11). Both the intensity and the distribution of specific eNOS, iNOS and nNOS staining were scored by using a histological score (H-Score) as previously described (12).

\section{Biochemistry}

Blood glucose level was determined during the experiment by using a glucometer. Plasma leptin levels were measured with radioimmunoassay (RIA) method via using Rat Leptin RIA kit (Linco Research, USA) at the end of the experiment.

\section{Statistical analysis}

Statistical analysis of the results was performed using GraphPad Prism version 5.02 for Windows (GraphPad Software, San Diego, CA, USA). One-way ANOVA analysis of variance was used, then the analyses were evaluated with post-hoc Tukey Multiple comparison test. Values for $\mathrm{p} \leq 0.05$ were considered statistically significant.

\section{Results}

Body weight loss, blood glucose levels and plasma leptin levels

The general characteristics of STZ-induced diabetic rats included reduced body weight and elevated blood glucose levels compared with control rats. In Lept group, rats did'nt gain the weight as much as Control or L-NAME groups. We observed that leptin and /or L-NAME had no effect on body weight loss in diabetic rats. The glucose levels of Lept group $(86.2 \pm 10.1 \mathrm{mg} / \mathrm{dl})$, L-NAME group $(82.6 \pm 5.5 \mathrm{mg} / \mathrm{dl})$ and STZ+L-NAME+Lept $(165.25 \pm 32.8 \mathrm{mg} / \mathrm{dl})$ were similar with Control group $(97.3$ $\pm 18.2 \mathrm{mg} / \mathrm{dl})$. The blood glucose levels increased in STZ (363.5 $\pm 42.6 \mathrm{mg} / \mathrm{dl})$, STZ+Lept $(324.8 \pm 154.4 \mathrm{mg} / \mathrm{dl})$, STZ+L-NAME $(235 \pm 58.1 \mathrm{mg} / \mathrm{dl})$ groups compared with control group $(\mathrm{p}<0.05)$. L-NAME treatment decreased glucose levels in diabetic rats $(\mathrm{p}<0.05)$.

The leptin level in Lept group $(1620 \pm 1544 \mathrm{pg} / \mathrm{ml})$ was similar with Cont group $(2980 \pm 1400 \mathrm{pg} / \mathrm{ml})(\mathrm{p}>0.05)$. The plasma leptin levels were significantly decreased in L-NAME $(440 \pm 600$ $\mathrm{pg} / \mathrm{ml}), \mathrm{STZ}(8 \pm 9 \mathrm{pg} / \mathrm{ml}), \mathrm{STZ}+$ Lept $(10 \pm 9 \mathrm{pg} / \mathrm{ml}), \mathrm{STZ}+\mathrm{L}-$ NAME $(1 \pm 0 \mathrm{pg} / \mathrm{ml})$ and STZ+L-NAME + Lept $(5 \pm 3 \mathrm{pg} / \mathrm{ml})$ groups when compared to Cont group $(\mathrm{p}<0.05)$. L-NAME and/ or leptin treatment had no effect on plasma leptin levels in diabetic rats $(\mathrm{p}>0.05)$.
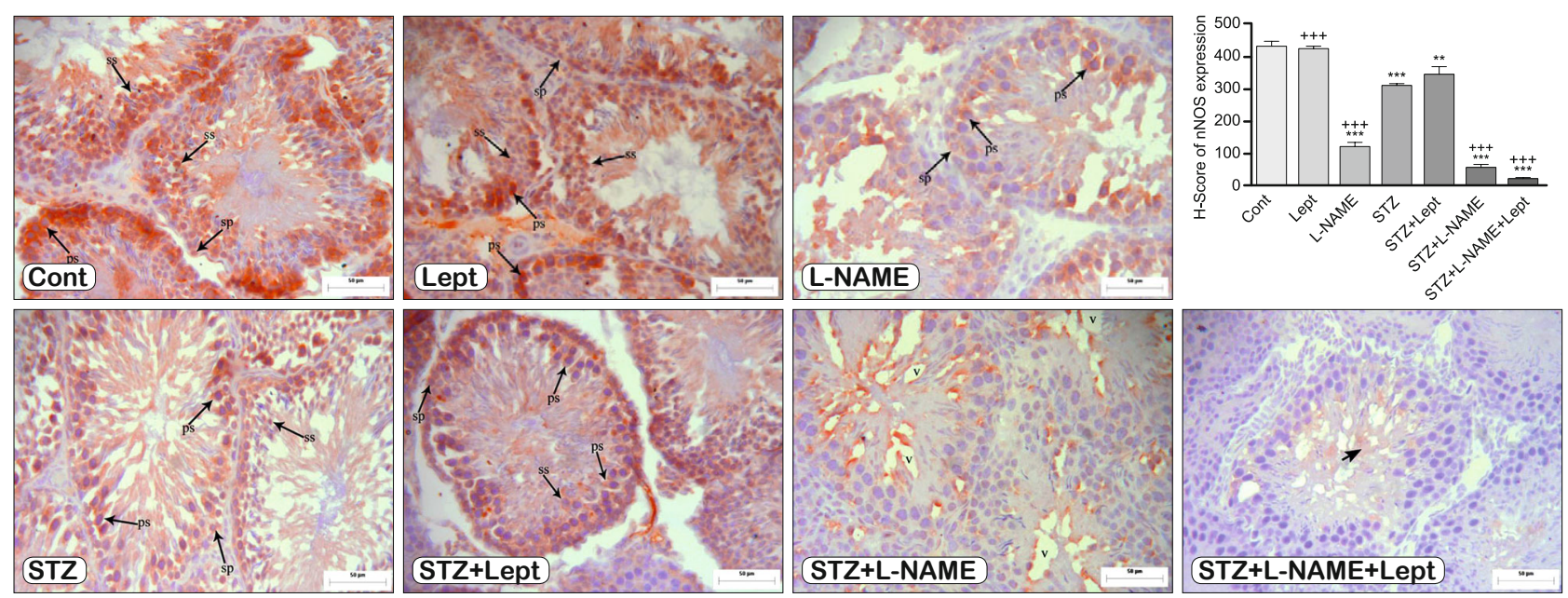

Fig. 1. Representative images for nNOS immunostaining and the graphic of H-score for nNOS immunoreactivity of testis for all groups. Immunoreactivity of nNOS in testis of groups. Spermatogonium (sp), Primary spermatocyte (ps), secondary spermatocyte (ss), Sertoli cell (s). Scale bars $=50 \mu \mathrm{m}$. *compared to control group, ${ }^{+}$compared to $\mathrm{STZ}$ group. ${ }^{* *} \mathrm{p}<0.01{ }^{* * *} \mathrm{p}<0.001,{ }^{+++} \mathrm{p}<0.001$. 

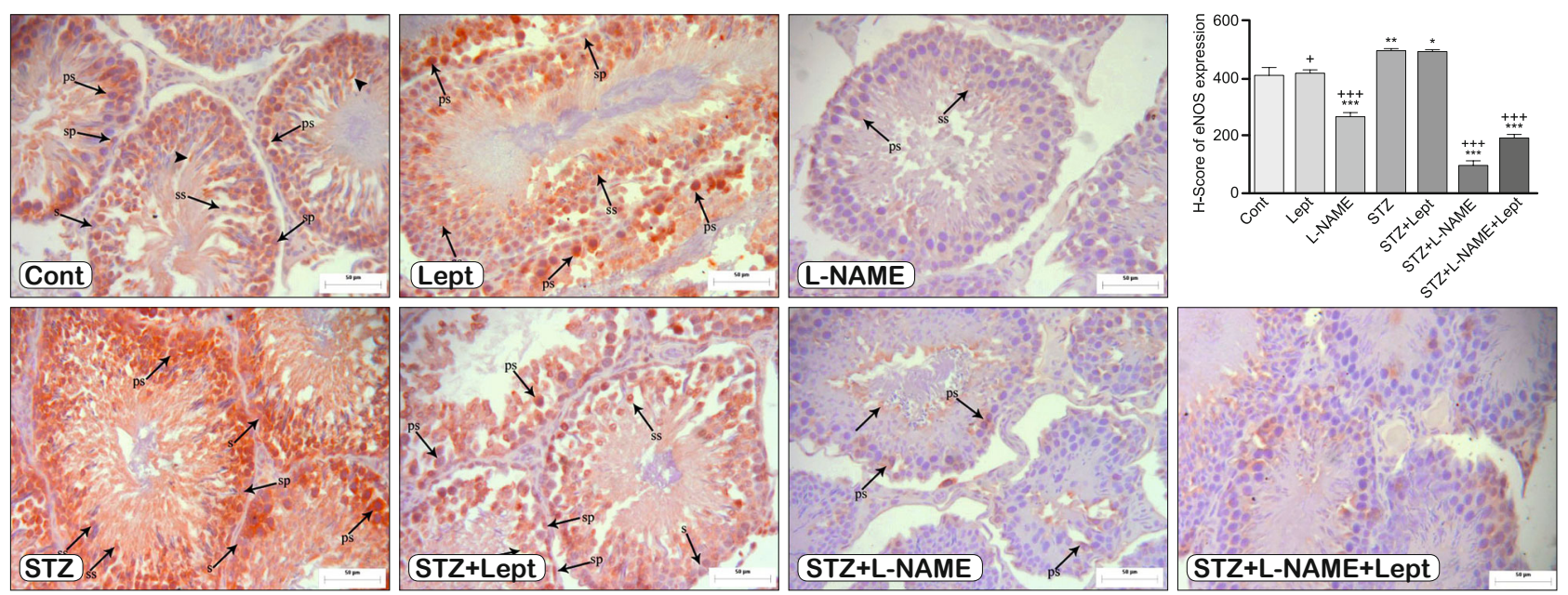

Fig. 2. Representative images for eNOS immunostaining, and the H-score for eNOS immunoreactivity of testis for all groups. Immunoreactivity of eNOS in testis of groups. Spermatogonium (sp), Primary spermatocyte (ps), secondary spermatocyte (ss), Sertoli cell (s), spermatid ( $\uparrow$ ). Scale bars $=50 \mu \mathrm{m}$. * compared to control group, ${ }^{+}$compared to STZ group. ${ }^{*} \mathrm{p}<0.05,{ }^{* *} \mathrm{p}<0.01{ }^{* * *} \mathrm{p}<0.001,{ }^{+} \mathrm{p}<0.05,{ }^{+++} \mathrm{p}<0.001$.
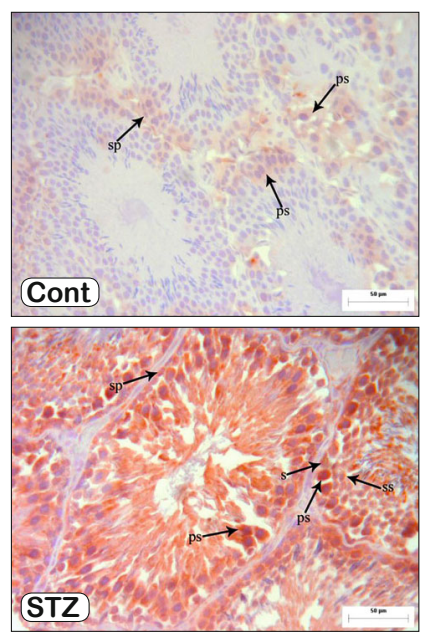
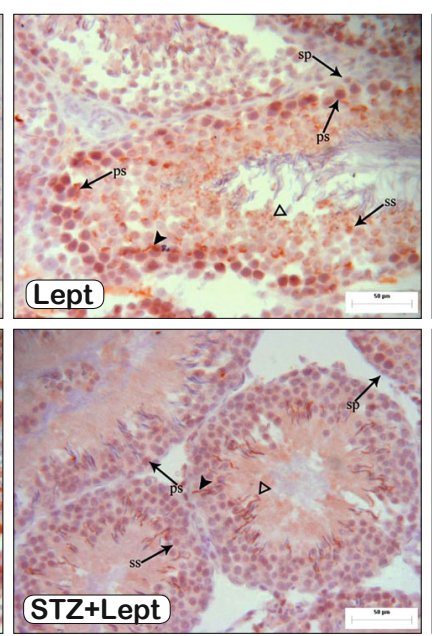
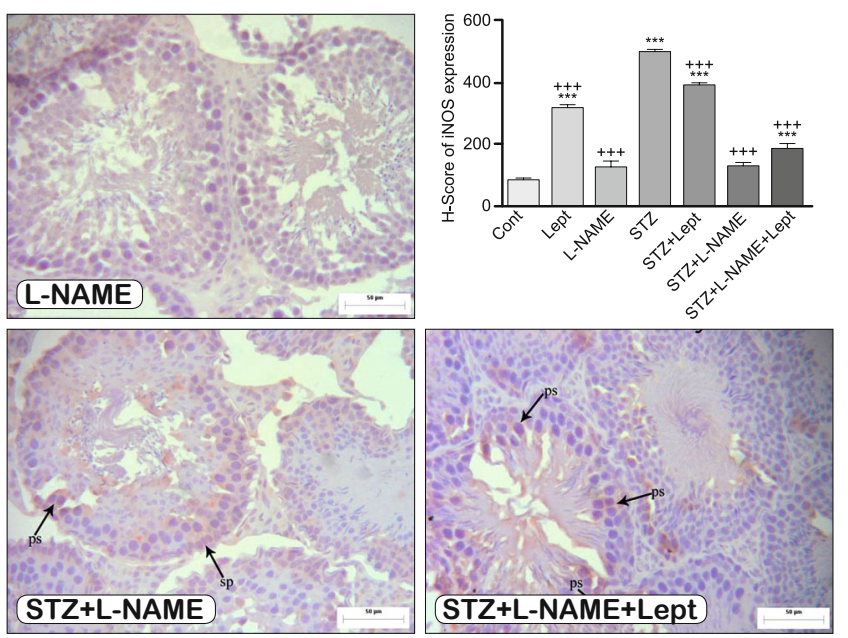

Fig. 3. Representative images for iNOS immunostaining, and the H-score for iNOS immunoreactivity of testis for all groups. Immunoreactivity of iNOS in testis of groups. Spermatogonium (sp), Primary spermatocyte (ps), secondary spermatocyte (ss), Sertoli cell (s), sperm ( $\Delta$ ), spermatid ( $\uparrow$ ). Scale bars $=50 \mu \mathrm{m}$. *compared to control group, ${ }^{+}$compared to STZ group. ${ }^{* * *} p<0.001,{ }^{+++} p<0.001$.

\section{Histopathological changes in testis tissue}

In the control group, the seminiferous tubules showed a normal architecture and germ cells in concentric layers. Also, spermatogenic cells at various stages of division were observed in the seminiferous tubules. In Lept and L-NAME groups, concentric germ cell layers were rarely disrupted compared to the control group and there were sperms with circular head, and spermatids with abnormal morphology. STZ caused a remarkably seminiferous tubule degeneration such as: atrophy, germ cell degeneration and connective tissue disruption. Leptin or L-NAME treatment mildly ameliorated the testicular damage in diabetic rats. Also, both L-NAME and leptin treatment ameliorated the testicular damage in diabetic rats.

\section{nNOS, eNOS and iNOS expression in testicular tissues}

Immunoreactivity of nNOS, eNOS and iNOS were observed in spermatogoniums, primary and secondary spermatocytes, Sertoli cells, spermatids and sperms by variable intensity in testis of groups. nNOS immunoreactivity was weaker in L-NAME $(\mathrm{p}<0.001)$, STZ $(\mathrm{p}<0.001)$, STZ+Lept $(\mathrm{p}<0.01)$, STZ+L-NAME $(\mathrm{p}<0.001)$ and $\mathrm{STZ}+\mathrm{L}-\mathrm{NAME}+$ Lept $(\mathrm{p}<0.001)$ groups in comparison to Cont group (Fig. 2).Also, nNOS immunoreactivity was weaker in STZ+LNAME $(p<0.001)$ and STZ+L-NAME+Lept $(p<0.001)$ and it didn't change in STZ+Lept group in comparison with STZ group. The least nNOS immunoreactivity was in STZ+L-NAME+Lept group (Fig. 1). Weaker eNOS immunoreactivity was detected in L-NAME $(\mathrm{p}<0.001), \mathrm{STZ}+\mathrm{L}-\mathrm{NAME}(\mathrm{p}<0.001)$ and STZ+L-NAME+Lept $(\mathrm{p}<0.001)$ groups in comparison to the Cont and STZ groups (Fig. 2). L-NAME treatment reduced the eNOS expression in diabetic rats' testes. iNOS immunoreactivity was more severe in $\operatorname{Lept}(\mathrm{p}<0.001)$, STZ $(\mathrm{p}<0.001)$, STZ+Lept $(\mathrm{p}<0.001)$ and STZ+L-NAME+Lept $(p<0.001)$ groups in comparison to Cont and STZ groups, also it was weaker in STZ+L-NAME group by STZ group (Fig. 3). 


\section{Discussion}

A chronic progressive metabolic disease DM can lead to various complications in male and female reproduction systems (13). We chose the well - established STZ-induced diabetic animal model, which appears as an increase in blood glucose level and decrement in body weight in agreement with other study groups $(14,15,16)$. On the other hand, alone or combined treatment of leptin and L-NAME didn't improve body weight loss in the diabetic rats. The effect of leptin on weight loss in STZ-induced diabetic rats may be related with the main task of leptin hormone, food intake and energy expenditure. Leptin suppresses neuropeptid Y (NPY), the hormone which stimulates food intake, and this results in inhibition of food intake and reduction in fat mass $(8,17)$. Chinookoswong et al. (1999) reported that $4 \mathrm{mg} / \mathrm{kg}$ leptin administration subcutaneously to STZ-induced diabetic rats restored euglycemia (18). In the present study, unrestored blood glucose concentration may be related to the leptin dose and duration of leptin treatment. One of the most important causes of damage to pancreatic $\beta$ cells in STZ-induced diabetes is oxidative stress, which develops as the result of an excessive increase in NO synthesis (19). In our study, L-NAME might be partially supressed by the NO production and due to this, blood glucose level partially reduced.

Plasma leptin levels were reduced in L-NAME group and in all the STZ treated groups in the present study. Plasma leptin level significantly decreased in STZ-induced diabetes due to insulin deficiency, and it increased rapidly with insulin administration (19, 20 ). Diabetes causes a production of excessive ROS such as NO. Exogenous leptin administration can protect the pancreas from the damage caused by reactive oxygen species without changing the plasma leptin levels (19). In our study, leptin treatment didn't cause any significant change in leptin concentration in STZ-induced diabetic rats and this might be related to the duration and dose of leptin administration.

STZ-induced diabetes model exhibits a dysfunction in the synthesis of hormones and sexual functions (13), decreases the sperm and germ sperm count and also vacuolization of Sertoli cells (2). In our study, we observed a degeneration in seminiferous tubules such as: atrophy and germ cell degeneration in diabetic rats in agreement with the studies $(2,16)$. Both eNOS and iNOS are thought to be associated with spermatogenesis, infertility, sperm maturation, and apoptosis of Sertoli and germ cells $(5,21)$. nNOS has been shown immunohistochemically in the cytoplasm of Sertoli cells (22). It is suggested that NOS types can be functional in tight junctions of Sertoli cells by affecting cAMP and cGMP. The tight junctions between the Sertoli cells in the basal part of the seminiferous epithelium in the testicle form blood-testis barriers, which provides the microenvironment necessary for the development of the germ cell $(21,23)$. In our study, the damage in semineferous tubules in diabetic rats might be related to an excessive NO synthesis by NOSs and this might be the cause of dysfunction in testis due to decreasing nNOS expression and increasing expression of eNOS and especially iNOS expression.
Leptin has various roles in the reproductive functions such as: $(8,23)$ puberty development and fertility regulation (24). Leptin and its receptors were detected in seminal plasma, and leptin receptors were showed in testis, Leydig cells and spermatozoa $(11,25,26)$. Also, leptin receptors were detected in hypothalamus and it was found that leptin stimulated NOS to produce $\mathrm{NO}$ and then NO stimulated the release of luteinizing hormone releasing hormone. Additionally, obesity, diabetes and infertility were observed in $\mathrm{db} / \mathrm{db}$ mice as well as abnormalities in growth and puberty development $(10,11,27)$. Exogeneous leptin treatment in diabetic rats resulted in the amelioration of the damage in seminiferous tubules in the present study. Leptin treatment might provide this by reducing iNOS expression, which is stimulated under pathological condition in diabetic rat testis. In rats with STZ administration, low plasma insulin levels have been shown to depend on leptin mRNA and plasma leptin concentrations (28) and insulin administration in diabetic rats increased leptin level (29). On the other hand, Wang et al. (2010) reported that leptin administration might have multiple short- and longterm advantages over insulin monotherapy for type 1 diabetes (30) and intracerebroventricular leptin treatment mediated antidiabetic actions in Type 1 diabetes (31). In our study, leptin treatment in diabetic rats might lead to an increase in insulin sensitivity.

In L-NAME treated rats, we observed some changes in seminiferous tubules. This might be related to the inhibition of NO synthesis. NO plays a role in regulating the reproduction system by using hypothalamus-pituitary-gonads axis. NO is necessary for the motility and capacitation of sperm $(6,32)$ and inhibition of NOS by L-NAME prevents the sperm motility (6). Another study reported that NO and NOS levels decreased, and germ cells were protected from the apoptosis by L-NAME $(10 / \mathrm{mg} / \mathrm{kg})$ treatment for 7 days in unilateral cryptorchidic rats (33). In our study, NOSs expressions in testis decreased by L-NAME administration for 7 days in L-NAME, STZ+L-NAME and STZ+L-NAME-Lept group, and also L-NAME treatment partially protected from the damage of excessive NO metabolites in diabetic rats.

In conclusion, L-NAME may reduce blood glucose by supressing an excessive NO production in diabetic rats. Detection of all three types of NOS isoforms in germ cells might indicate that $\mathrm{NO}$ is produced in all germ cells. An increased expression of eNOS and iNOS and a decrease in nNOS expression causes histopathological changes in STZ-induced diabetes. Leptin treatment partially recovered the damage in diabetic rats by reducing iNOS expression. Also, L-NAME treatment partially prevented the damage in testicular tissue by supressing NOSs and by reducing the NO level expression in diabetic rats. It can be suggested that leptin and L-NAME partially prevents testicular damage by ameliorating the histopathological changes by stimulating and /or supressing three types of NOS expression in diabetic rats. Also, this is the first report demonstrating the relationship between leptin and nitric oxide in testicular tissue in STZ -induced diabetic rats. 


\section{References}

1. Baccetti B, Marca A, Piomboni P, Capitani S, Bruni E, Petraglia F, De Leo V. İnsulin-dependent diabetes in men is associated with hypothalamo-pituitary derangement and with impairment in semen quality. Hum Reprod 2002; 17: 2673-2677.

2. Altay B, Cetinkalp S, Doganavsargil B, Hekimgil M, Semerci B. Streptozotocin-induced diabetic effects on spermatogenesis with proliferative cell nuclear antigen immunostaining of adult rat testis. Fertil Steril 2003; 80 (2): 828-831.

3. Ballester J, Munoz MC, Dominguez J, Guinovart JJ, RodriguezGill JE. İnsulin dependent diabetes affects testicular function by FSH- and LH-linked mechanisms. J Androl 2004; 25 (5): 706-719.

4. Nathan C. Nitric oxide as a secrotory product of mammalian cells. FASEB J 1998; 6: 3051-3064.

5. Li Mx, He Lp, Guo Zq, Liu Ys, Long Zf. The expression of nitric oxide synthase in testes of male rat. Zhonghua Nan Ke Xue 2002; 8 (4): 250-252.

6. Revelli A, Costamagna C, Moffa F, Aldieri E, Ochetti S, Bosia A, Massobrio M, Lindblom B, Ghigo D. Signaling Pathway of Nitric Oxide-Induced Acrosome Reaction in Human Spermatozoa. Biol Reprod 2001; 64: 1708-1712.

7. Zhang F, Chen Y, Heiman M, Dimarchi R. Leptin: Structure, Function and Biology. Vitam Horm 2005; 71: 345-372.

8. Moran O, Phillip M. Leptin: obesity, diabetes, and other peripheral effects - a review. Pediatr Diabetes 2003; 4: 101-109.

9. Andreelli F, Hanaire- Broutin H, Laville M, Tauber JP, Riou JP, Thiovolet C. Normal Reproductive Function in Leptin-Deficient patients with Lipoatropic Diabetes. J Clin Endocrinol Metab 2000; 85 (2): $715-719$.

10. Park JY, Chong AY, Cochran EK, Kleiner DE, Haller MJ, Schatz DA, Gorden P. Type 1 diabetes associated with acquired generalized lipodystrophy and insulin resistance: the effect of long-term leptin therapy. J Clin Endocrinol Metab 2008; 93 (1): 26-31.

11. Oztay F, Kandil A, Gurel E, Ustunova S, Kapucu A, Balci H, Akgun-Dar K, Demirci C. The relationship between nitric oxide and leptin in the lung of rat with streptozotocin-induced diabetes.Cell Biochem Funct 2008; 26 (2): 162-171.

12. Kapucu A. Effects of erythropoietin on nitric oxide synthase types in the hippocampus and frontal cortex in PTZinduced seizures in rats. J Ist Faculty Med 2019; 82 (2): 107-115

13. Lin SH, Wang ZS. Study on the Expresssion of Androgen Receptor in Testis, Epydidymis and Prostate of Adult Rats with Diabetes. Zhonghua Nan Ke Xue 2005; 11 (12): 891-894.

14. Gurel E, Ustunova S, Kapucu A, Yilmazer N, Eerbeek O, Nederlof $\mathbf{R}$, Zuurbier CJ. Hexokinase cellular trafficking in ischemia-reperfusion and ischemic preconditioning is altered in type I diabetic heart. Mol Biol Rep 2013; 40 (7): 4153-4160.

15. Heeba GH, Hamza AA. Rosuvastatin ameliorates diabetes-induced reproductive damage via suppression of oxidative stress, inflammatory and apoptotic pathways in male rats. Life Sci 2015; 141: 13-19.

16. Kumas M, Altintas O, Esrefoglu M. Protective effect of ischemic preconditioning on testis injury following transient focal cerebral ischemia in diabetic rats. Bratisl Lek Listy 2017; 118 (9): 557-563.
17. Ahima RS, Osei SY. Leptin Signaling. Physiol Behav 2004; 81: 223-241.

18. Chinookoswong N, Wang JL, Shi ZQ. Leptin restores euglycemia and normalizes glucose turnover in insulin-deficient diabetes in the rat. Diabetes 1999; 48 (7): 1487-1492.

19. Gülen Ş, Dinçer S. Effects of leptin on oxidative stress in healthy and Streptozotocin-induced diabetic rats. Mol Cell Biochem 2007; 302 (1-2): 59-65.

20. Sivitz WI, Walsh S, Morgan D, Donohoue P, Haynes W, Leibel RL. Plasma leptin in diabetic andinsulin-treated diabetic and normal rat. Metabolism 1998; 47 (5): 584-591.

21. Lee NPY, Cheng CY. Regulation of sertoli Cell Tight Junction Dynamics in the Rat Testis via the Nitric oxide Synthase/Soluble Guanylate Cyclase/3',5'-Cyclic Guanosine Monophosphate/Protein Kinase G Signaling Pathway: an in Vitro Study. Endocrinology 2003; 144 (7): 3114-3129.

22. Celik-Ozenci C, Bayram Z, Akkoyunlu G, Korgun E.T, Erdogru T, Seval Y, Ustunel I, Baykara M, Demir R. Localization of NGF and nNOS in varicocele-induced rat testis. Acta Histochem 2006; 107 (6): 435-442.

23. Mruk DD, Cheng CY. Sertoli-Sertoli and Sertoli-germ cell interactions and their significiance in germ cell movement in the seminiferous epithelium during spermatogenesis. Endocr Rev 2004; 25 (5): 747-806.

24. Tena-Sempere M, Barreiro ML. Leptin in male reproduction: the testis paradigm. Mol Cell Endocrinol 2002; 25; 188 (1-2): 9-13.

25. Caprio M, Fabbrini E, Ricci G, Basciani S, Gnessi L, Arizzi M, Carta AR, Martino MU, Isidori AM, Frajese GV, Fabbri A. Ontogenesis of Leptin Receptor in Rat leydig Cells. Biol Reprod 2003; 68: 1199-1207.

26. Jope T, Lammert J, Paasch U, Glander HJ. Leptin ande leptin receptor in human seminal plasma and in human spermatozoa. Int J Androl 2003; 26 (6): 335-341.

27. Bates SH, Stearns WH, Dundon TA, Schubert M, Tso AW, Wang Y, Banks AS, Lavery HJ, Haq AK, Maratos-Flier E, Neel BG, Scwartz MW, Myers MG. STAT3 signaling is required for leptin regulation of enetgy balance not reproduction. Nature 2003; 421 (6925): 856-859.

28. Patel BK, Koenig JI, Kaplan LM, Hooi SC. Increase in plasma leptin and Lep mRNA concentrations by food intake is dpendent on insulin. Metabolism 1998; 47 (5): 603-607.

29. Ishii S, Kamegai J, Tamura H, Shimizu T, Sugihera H, Okawa S. Role of ghrelin in streptozotocin-induced diabetic hyperphagia. Endocrinology 2002; 143 (12): 4934-4937.

30. Wang MY, Chen L, Clark GO, Lee Y, Stevens RD, Ilkayeva OR, Unger RH. Leptin therapy in insulin-deficient type I diabetes. Proc Natl Acad Sci 2010; 107 (11): 4813-4819.

31. Fujikawa T, Chuang JC, Sakata I, Ramadori G, Coppari R. Leptin therapy improves insulin-deficient type 1 diabetes by CNS-dependent mechanisms in mice. Proc Natl Acad Sci 2010; 107 (40): 17391-17396.

32. Lewis SE, Donnelly ET, Sterling ES, Kennedy MS, Thompson W, Chackravarthy U. Nitric oxide synthase and nitrite production in human spermatozoa: evidence that endogenous nitric oxide is beneficial to sperm motility. Mol Hum Reprod 1996; 2 (11): 8873-8878.

33. Gao XK, Yang B, Wang H, Shao C, Liu HL, Shao GX. Protective effect of nitric oxide synthase inhibitor (L-NAME) on germ cell apoptosis in experimentally cryptorchid rat. Zhonghua Nan Ke Xue 2003; 9 (9): 684-689. 